doi: 10.2306/scienceasia1513-1874.2014.40.317

\title{
Length-weight relationship and trophic level of hard-tail scad Megalaspis cordyla
}

\author{
Simon Kumar Das ${ }^{\mathrm{a}, \mathrm{b}, *}$, Moumita De ${ }^{\mathrm{a}}$, Mazlan Abd. Ghaffar ${ }^{\mathrm{b}, \mathrm{c}}$ \\ a School of Environmental and Natural Resource Sciences, Faculty of Science and Technology, \\ University Kebangsaan Malaysia, 43600 UKM Bangi, Selangor, D.E., Malaysia \\ b Marine Ecosystem Research Centre (EKOMAR), Faculty of Science and Technology, \\ University Kebangsaan Malaysia, 43600 UKM Bangi, Selangor D.E., Malaysia \\ c Institute of Tropical Aquaculture, University of Malaysia Terengganu, 21030, Kuala Terengganu, Malaysia
}

*Corresponding author, e-mail: skdas_maa@yahoo.com, simon@ukm.edu.my

Received 20 Feb 2014

Accepted 26 Sep 2014

\begin{abstract}
Megalaspis cordyla popularly known as hard-tail scad or torpedo scad is a commercially important fish in Malaysia. The present study describes the length-weight relationship and trophic level of $M$. cordyla collected from the coastal waters of Tanjung Sepat, Selangor, Malaysia from December 2010 to November 2011. A total of 375 specimens ranging from $17.3-37.5 \mathrm{~cm}$ total length and 52.40-451.12 $\mathrm{g}$ body weight were analysed in this study. The growth form meant that the allometric coefficient $b$ of the length-weight relationships was less than three, suggesting negative allometric growth for males $(b=2.65)$, females $(b=2.77)$, and combined sex $(b=2.64)$. The regression coefficient was not significantly different between the sexes. Stomach content analysis revealed that both males and females fed mostly on teleost (90\%, $88 \%$ ) followed by crustaceans $(7 \%, 8 \%)$ and molluscs $(4 \%, 4 \%)$, respectively. The estimated mean trophic level for the males and females were $3.67 \pm 0.04$ and $3.84 \pm 0.05$, respectively, indicating that they are largely carnivorous. In this study we found less diverse diets compared to previous reports, which might be indicative of anthropogenic disturbance to their food chain and ecosystem.
\end{abstract}

KEYWORDS: population growth, pelagic fish, feeding niche, diet, tropical waters

\section{INTRODUCTION}

Megalaspis cordyla (Linnaeus 1758), commonly known as hard tail scad or torpedo scad, is a tropical to subtropical euryhaline fish, occupying diverse habitats. It is widely distributed throughout the tropical Indo-Pacific region, ranging from East Africa to Japan and Australia ${ }^{1}$. M. cordyla is a schooling pelagic fish and inhabits surface layers of both inshore and offshore oceanic waters ${ }^{2}$. M. cordyla is of commercial importance in the wild fishery in Malaysia, with annual catches estimated at 22000 tonne, making up $15-20 \%$ of the total pelagic catch ${ }^{1}$. In spite of their commercial value and the long-standing interest in this fish, very few studies have been conducted in Malaysia. Nevertheless, research has been conducted on this species elsewhere (e.g., India, Bangladesh) investigating; larval development ${ }^{3}$, anatomy ${ }^{4}$, sex ratio, length at first maturity, spawning season ${ }^{5}$, morphometric measurement (e.g., body shape measurement), meristic counts (e.g., number of fin rays $)^{6}$, occurrence of heavy metals in tissue ${ }^{7,8}$, feeding habits ${ }^{9}$, age and growth ${ }^{10}$, and growth form (length-weight relation- ship) ${ }^{11-14}$.

There are data which suggest that length-weight relationships (LWR) are useful in fishery management namely, to: (i) estimate body weight from length observation (ii) calculate production and biomass of a fish population; and (iii) provide information on stocks or organism condition at the corporal level ${ }^{15,16}$.

Apart from LWR, the quality and quantity of food consumed are considered important exogenous factors that have an effect on growth and overall wellbeing of fish $^{17}$. The analysis of stomach contents can provide essential information about the diet and trophic level of a species and this has become a standard practice in fisheries ecology because it provides numerical values of trophic position in fishes (e.g., trophic level $>4=$ piscivores) ${ }^{18}$. Although there have been some reports on the trophic level of M. cordyla in Indian waters ${ }^{9}$, no report is available on this important exogenous factors in Malaysian waters. In addition, there is a scarcity of information on LWR of M. cordyla in Malaysian waters despite their abundance and commercial importance $^{19}$.

The objectives of this study were to describe 
the length-weight relationship and trophic level of M. cordyla collected from the coastal waters of Tanjung Sepat, Selangor, Malaysia.

\section{MATERIALS AND METHODS}

\section{Field sampling}

Sampling was carried out monthly in the coastal waters of Tanjung Sepat $\left(2^{\circ} 41^{\prime} 56.60^{\prime \prime} \mathrm{N}, 101^{\circ} 27^{\prime} 16.38^{\prime \prime}\right.$ $\mathrm{E}$ and $2^{\circ} 36^{\prime} 52.29^{\prime \prime} \mathrm{N}, 101^{\circ} 36^{\prime} 13.29^{\prime \prime} \mathrm{E}$ ), Selangor, Malaysia from December 2010 to November 2011. The samples were collected on board a local fishing vessel using trawl nets $(20 \mathrm{~m}$ foot rope opening with $5 \mathrm{~m}$ height and $3.5 \mathrm{~cm}$ cod end mesh size). Upon capturing, the total length $(L)$ (tip of the upper jaw to tip of the caudal fin) and body weight $(W)$ of the fish samples $(N=375)$ were measured to the nearest $0.1 \mathrm{~cm}$ and $0.1 \mathrm{~g}$, respectively ${ }^{20-22}$. A subsample of 210 fish comprising 105 males and 105 females of varying sizes (representing all size classes) were injected with $4 \%(\mathrm{w} / \mathrm{v})$ formaldehyde into the body cavity soon after body weight measurement to prevent further digestion and decomposition of the stomach content $^{23}$. All specimens were sexed by gonad observation under a binocular microscope ${ }^{24}$.

\section{Length-weight relationship}

The relationship between length and weight of a fish is usually expressed by the equation ${ }^{25} W=a L^{b}$ where $W$ is the body weight in $\mathrm{g}$, and $L$ is the total length in $\mathrm{cm}$. The coefficient $a$ is the intercept in the $y$ axis, and the allometric or regression coefficient $b$ is an exponent indicating isometric growth when equal to 3. The parameters $a$ and $b$ were estimated by nonlinear regression. Curve fitting was carried out by an iterative method using $\chi^{2}$ goodness of fit test using Microcal ORIGIN 8.0 (OriginLab, Northampton, MA) ${ }^{23,26}$. The measurement of model fit (goodness of fit of calculated $L$ and $W$ ) was evaluated by the coefficient of determination $\left(r^{2}\right)$. Student's $t$-tests ${ }^{27}$ were performed to test whether the computed value of $b$ was significantly different from three, indicating the type of growth ${ }^{28}$ : isometric $(b=3)$, positive allometric $(b>3)$, or negative allometric $(b<3)$, and to compare the regression coefficients $b$ for possible significant differences between male and female. In addition, the analysis of covariance (ANCOVA) was also applied to evaluate the homogeneity of the regression slopes whereby $\log$ weight was modelled as a function of sex, covariate (i.e., log length), and their interaction. The interaction term tested for homogeneity of the slopes. The computer software MinitAB 17 was used for the statistical analysis. Statistical differences were considered significant when $p<0.05$.

\section{Trophic level analysis}

Trophic level of males (105) and females (105) were analysed based on the stomach content analysis. Stomach contents were analysed under the microscope $^{29,30}$ to identify prey items and frequency of occurrence $^{18,31}$. Finally, the trophic level of individual fish was estimated using TROPHLAB ${ }^{32}$ with

$$
\mathrm{TROPH}_{i}=1+\sum_{j=1}^{G} \mathrm{DC}_{i j} \times \mathrm{TROPH}_{j}
$$

where $\mathrm{TROPH}_{j}$ is the fractional trophic level of prey $j, \mathrm{DC}_{i j}$ represents the fraction of $j$ in the diet of an individual fish $i$, and $G$ is the total number of prey species in a stomach. Thus defined, the trophic level ranges between 2.0 for herbivorous/detritivorous and 5.0 for piscivorous/carnivorous species ${ }^{33,34}$. The mean values $( \pm$ S.E.) estimated from the equation were input into the MICROCAL ORIGIN 8.0 graphic software (OriginLab, Northampton, MA) ${ }^{23}$ for acquiring the trophic position pattern according to the fish size class.

\section{RESULTS AND DISCUSSION}

A total of 375 specimens were collected during the study period; 200 males and 175 females. The male samples ranged from $17.3-35.5 \mathrm{~cm}$ in $L$, and 52.4 $446.0 \mathrm{~g}$ in $W$; female samples ranged from 20$37.5 \mathrm{~cm}$ in $L$ and 79.43-470.56 $\mathrm{g}$ in $W$.

\section{Length-weight relationship}

The LWR indicated negative allometric growth in male $\left(W=0.034 L^{2.65}\right)$, female $\left(W=0.021 L^{2.77}\right)$, and combined sex $\left(W=0.034 L^{2.64}\right)$ of $M$. cordyla samples, meaning that their length increases faster than their body weight (Fig. 1). The calculated regression coefficients $b$ were significantly $(p<0.05)$ lower than 3 for males $(p<0.05$, df $=198, \mathrm{SE}=$ $0.07)$, females $(p<0.05$, df $=173, \mathrm{SE}=0.05)$, and combined sex $(p<0.05$, df $=371, \mathrm{SE}=0.04)$, indicating negative allometric growth. The correlation coefficient values $\left(r^{2}>0.90\right)$ revealed that the observed and calculated length and weight relationship was closely fitted (Fig. 1).

The $t$-test for the comparison of the regression coefficients between the sexes was not significant $(t=0.563$, df $=371, p=0.287)$. Similarly, ANCOVA analysis showed that the interaction between the covariate (log length) and sex was not significant $(F=0.61$, df $=(1,371), p=0.578)$. This indicates 

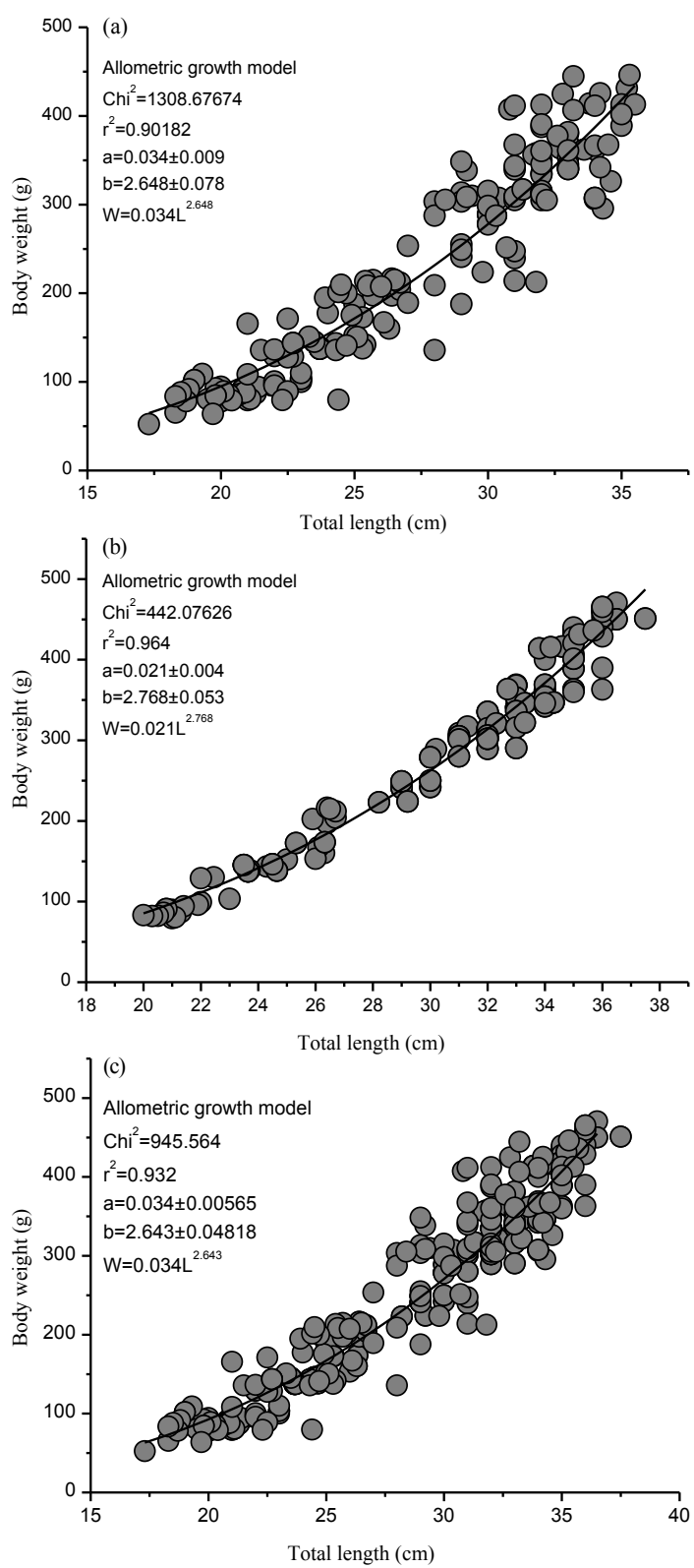

Fig. 1 Length-weight relationships of Megalaspis cordyla (a) males, (b) females, (c) combined sex. Line represents nonlinear fit whereas circles represent individuals.

that there was no significant difference in the LWR for different sexes.

The allometric coefficients (b) estimated in this study (2.64-2.78) were within the expected range of 2-4 commonly observed in teleost ${ }^{16,35}$. The present findings are in agreement with previous studies on this species where negative allometric growth $(b<3)$ has been reported ${ }^{9,10,13}$, except in one study ${ }^{11}$ in which isometric growth $(b=3.0)$ for male, female and combined sex of M. cordyla in Mumbai waters was observed (Table 1). These variations in allometric coefficient for M. cordyla in the Mumbai coast might be attributed to differences in sample size and different locations ${ }^{36}$. Moreover, other factors including temperature, food (quantity, quality, and size), and stage of maturity may also account for the differences in allometric coefficient values of fishes ${ }^{37-39}$ namely, Panda et al $^{11}$ reported isometric growth form for M. cordyla in Mumbai waters whereas our study found negative allometric growth for male, female and combined sex. The regression model fitting in the present study showed that $L$ and $W$ of the fish are highly correlated $\left(r^{2}=0.90-0.96\right)$, which is consistent with Panda et $\mathrm{al}^{11}$.

\section{Trophic level analysis}

A total of 210 specimens (105 males and 105 females) were examined, $5 \%$ and $10 \%$ of the stomachs were empty for males and females, respectively. Three families of crustacean, two families of mollusc and six species of fish were identified (Table 2). After grouping all food items into three categories, teleost were the main prey items observed in male and female stomachs $(90 \%$ and $88 \%$ ), followed by crustaceans (7\% and $8 \%$ ) (Table 2), and mollusc (4\% and $4 \%$ ), respectively. Among the identified teleost species Leiognathus sp. formed the majority of the diet by weight $71 \mathrm{~g}$ and $89 \mathrm{~g}$ in male and female samples, respectively, as shrimp and copepods occurred most frequently in male (frequency of occurrence $f o=$ $86 \%, 81 \%)$ and female $(f o=90 \%, 76 \%)$ samples (Table 2), respectively. Frequency of occurrence of the major food categories did not differ between sexes (e.g., difference observed 4-5\%), although more prey items were observed in female stomachs. The reason might be the females were bigger in size than males. It was observed that crustaceans formed the majority of the diet by number whereas teleost formed the majority of the diet by weight in both sexes and size classes (Table 2).

In the present study the stomach content analysis shows that the diets of male and female $M$. cordyla includes crustaceans, teleosts, and molluscs, which is consistent with Sivakami's ${ }^{9}$ results. However, Sivakami ${ }^{9}$ reported that $M$. cordyla in Indian waters also takes other fishes: Silverbellies, Nemipterids, flatfishes, perches; crustaceans: Cladocerans, Squilla spp., alima larvae; molluscs: Morula sp., Nucula sp., Cavolina sp., juvenile squids; detritus, and even sand particles, which were not found in the present study. The feeding niche of this pelagic species largely depends on the food availability and ecosystem 
Table 1 Length-weight relationship in M. cordyla compared to previous studies.

\begin{tabular}{|c|c|c|c|c|c|c|c|}
\hline \multirow[t]{2}{*}{ Author(s) } & \multirow[t]{2}{*}{ Area of study } & \multicolumn{2}{|c|}{ Male } & \multicolumn{2}{|c|}{ Female } & \multicolumn{2}{|c|}{ Combined sex } \\
\hline & & $a^{\dagger}$ & $b^{\dagger}$ & $a$ & $b$ & $a$ & $b$ \\
\hline \multirow[t]{3}{*}{ Reuben et al ${ }^{13}$} & East coast of India & - & - & - & - & 0.000012 & 2.94 \\
\hline & North-west coast of India & - & - & - & - & 0.000127 & 2.52 \\
\hline & South-west coast of India & - & - & - & - & 0.000050 & 2.72 \\
\hline Saker et al ${ }^{10}$ & Mumbai coast, India & 0.00007 & 2.64 & 0.00020 & 2.46 & 0.000010 & 2.88 \\
\hline Sivakami $^{9}$ & Cochin, India & 0.01741 & 2.58 & 0.00865 & 2.86 & 0.013419 & 2.69 \\
\hline Zafar et $\mathrm{al}^{14}$ & Bangladesh & - & - & - & - & 0.017940 & 2.82 \\
\hline Panda et al ${ }^{11}$ & Mumbai, India & 0.01119 & 2.92 & 0.00713 & 3.08 & 0.008577 & 3.02 \\
\hline Present study & Malaysia & 0.03400 & 2.65 & 0.02100 & 2.77 & 0.034000 & 2.64 \\
\hline
\end{tabular}

$\dagger a$ is the intercept and $b$ is the allometric/regression coefficient.

Table 2 Prey items observed in 210 M. cordyla (105 male, and 105 female) stomachs from coastal waters of Tanjung Sepat Selangor, Malaysia, grouped by major categories.

\begin{tabular}{|c|c|c|c|c|c|c|c|c|c|c|c|c|}
\hline \multirow[t]{2}{*}{ Prey category } & \multicolumn{6}{|c|}{ Male } & \multicolumn{6}{|c|}{ Female } \\
\hline & $N^{\dagger}$ & $W(\mathrm{~g})^{\dagger}$ & $\% \mathrm{wt}^{\dagger}$ & $n^{\dagger}$ & $f_{o}(\%)^{\dagger}$ & $w(\mathrm{~g})^{\dagger}$ & $N$ & $W(\mathrm{~g})$ & $\% \mathrm{wt}$ & $n$ & fo $(\%)$ & $w(\mathrm{~g})$ \\
\hline \multicolumn{13}{|l|}{ Shrimp } \\
\hline Penaeidae & 154 & 14 & 5 & 90 & 86 & 0.13 & 176 & 22 & 7 & 95 & 90 & 0.21 \\
\hline Copepod & & & & & & & & & & & & \\
\hline Corycaeidae & 75 & 2 & 0.70 & 85 & 81 & 0.01 & 87 & 2 & 0.6 & 80 & 76 & 0.02 \\
\hline $\begin{array}{l}\text { Amphipod } \\
\text { Pontogeneiidae }\end{array}$ & & & 080 & & & & & & & & & \\
\hline Total Crustacea & 293 & 18 & $\begin{array}{c}0.00 \\
6.5\end{array}$ & $250^{*}$ & 238 & $\begin{array}{l}0.02 \\
0.16\end{array}$ & $\begin{array}{l}15 \\
338\end{array}$ & $\begin{array}{c}2 \\
26\end{array}$ & $\begin{array}{c}0.4 \\
8\end{array}$ & $252^{*}$ & $\begin{array}{c}73 \\
239\end{array}$ & $\begin{array}{l}0.02 \\
0.25\end{array}$ \\
\hline Leiognathus sp. & 75 & 71 & 27 & 55 & 52 & 0.67 & 100 & 89 & 29 & 60 & 57 & 0.85 \\
\hline Gazza sp. & 35 & 61 & 23 & 25 & 24 & 0.58 & 27 & 53 & 17 & 20 & 19 & 0.50 \\
\hline Caranx sp. & 20 & 32 & 12 & 12 & 11 & 0.31 & 24 & 41 & 13 & 17 & 16 & 0.39 \\
\hline Scomberomorus sp. & 17 & 28 & 11 & 10 & 10 & 0.27 & 17 & 36 & 12 & 9 & 9 & 0.34 \\
\hline Stolephorus sp. & 16 & 23 & 9 & 9 & 9 & 0.22 & 15 & 30 & 10 & 10 & 10 & 0.29 \\
\hline Apogon sp. & 13 & 21 & 8 & 10 & 10 & 0.20 & 10 & 19 & 7 & 7 & 7 & 0.18 \\
\hline Total teleost & 176 & 236 & 90 & $121^{*}$ & 116 & 2.25 & 193 & 268 & 88 & $123^{*}$ & 118 & 2.55 \\
\hline \multicolumn{13}{|l|}{ Bivalvia } \\
\hline Mactridae & 65 & 8 & 3 & 35 & 33 & 0.07 & 77 & 8 & 3 & 27 & 26 & 0.08 \\
\hline Lucinidae & 10 & 1 & 0.50 & 5 & 5 & 0.01 & 30 & 3 & 1 & 14 & 13 & 0.03 \\
\hline Total mollusc & 75 & 9 & 3.50 & $40^{*}$ & 38 & 0.08 & 107 & 11 & 4 & $41^{*}$ & 39 & 0.11 \\
\hline Grand total & 544 & 263 & 100 & 411 & 392 & 2.49 & 638 & 305 & 100 & 416 & 396 & 2.91 \\
\hline
\end{tabular}

${ }^{\dagger} N$ : number of individuals of prey category; $W$ : total weight; \% wt: percent by weight; $n$ : number of stomachs with prey item; fo: frequency of occurrence; $w$ : total weight of prey category per stomach.

* the cumulative prey items in each category

health, and larger individuals in healthy ecosystems tend to consume more diversified food in comparison to smaller fish and those in unhealthy ecosystems, particularly ecosystems with high fishing pressure. The limited diversity of food items in the diets of the fish studied here may also reflect the short duration of our study, since diet changes with season and availability and therefore longer-term studies will inevitably report a great diversity of food items potentially eaten by a species then short term studies. Diversity of diet is also affected by body size and therefore gapes, since fish are gape limited. Despite these limitations the diversity of diet may also reflect the diversity available to the species, which may be a direct reflection of low species richness in their ecosystem and therefore poor ecosystem health.

The estimated trophic levels were $3.67 \pm 0.04$ for males and $3.84 \pm 0.05$ for females (Fig. 2). Similar trophic levels were also reported by Blaber et al ${ }^{40}$ for $M$. cordyla in coastal waters of Solomon islands and Simon et al $^{23}$ for Toxotes chatareus and T. jaculatrix in Malaysian waters, and Stergiou and Karpouzi ${ }^{41}$ for Gadiculus argenteus argenteus, Trachurus mediterraneus, and $T$. trachurus in Mediterranean waters. All these species exhibit similar feeding preferences, namely, crustaceans, teleosts, and mollusc and can be considered as carnivores. Trophic levels in both sexes gradually increased with size (Fig. 2).

This study has described the length-weight relationship and diet of M. cordyla in Malaysian coastal 

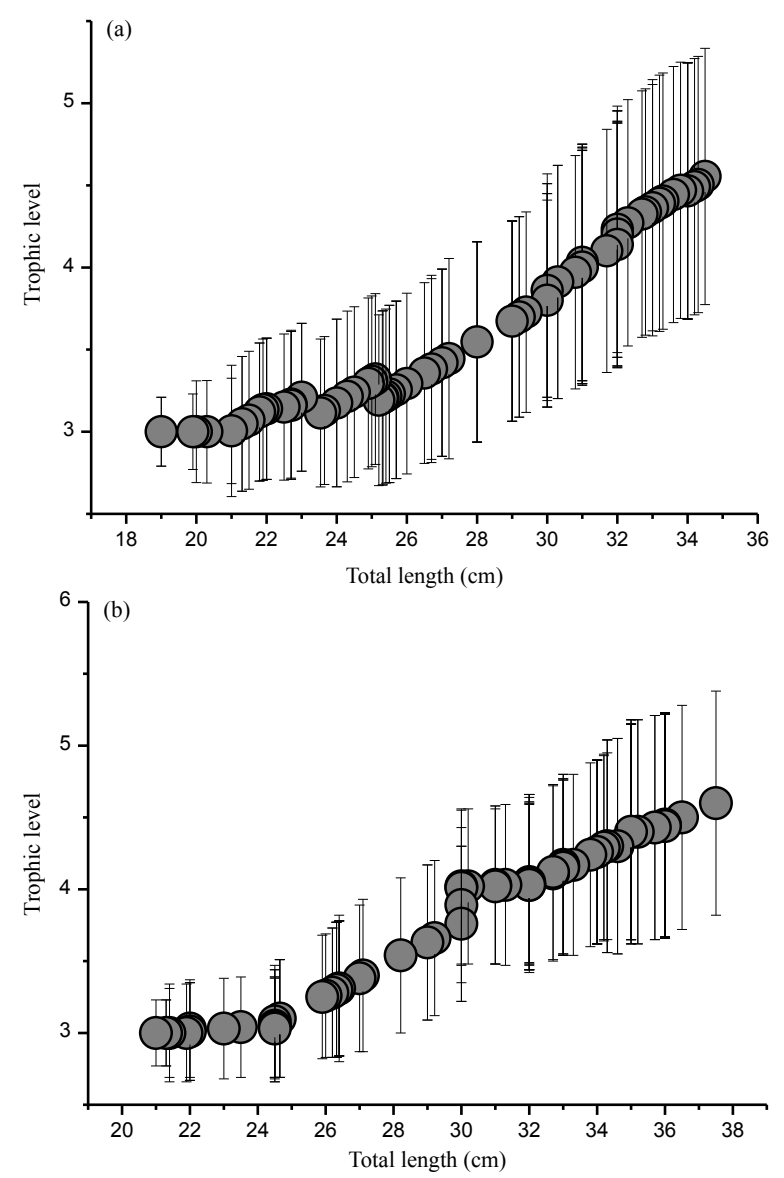

Fig. 2 Trophic level-size relationship of $M$. cordyla (a) males and (b) females (circles represent mean trophic level estimated by TROPHLAB program and bars represent variants of prey items).

waters. The population size $(N=375)$ used in the present study is considered small and might have the effect on the negative allometric growth of $M$. cordyla. Moreover, the feeding niche of fishes depends on ecosystem health and as the Indian Ocean is healthier than Malaysian waters we found less diverse food items in the stomach contents, although the calculated trophic level indicated a carnivorous feeding habit. As no information exists on the biological aspects of this fish in Malaysian coastal waters, the present findings will be of use as a reference for future works not only in Malaysia but also in nearby areas of this country.

Acknowledgements: We would like to thank, the two anonymous reviewers for their useful comments that greatly improved the quality of the manuscript. Many helpful comments on earlier drafts of this paper have also been provided by Dr Shelby E. Temple, Dr Yosni Bakar, and Dr Saleh M. Rahim. We appreciate the Ichthyology lab technicians of Universiti Kebangsaan Malaysia for their efforts during sampling. Thanks to Institute of Climate Change, Universiti Kebangsaan Malaysia for financial support through Young Researcher Incentive Grant GGPM-2011-057 and University research grant GUP-2013-006. All field sampling and laboratory protocols followed and complied with in the current laws of Malaysia.

\section{REFERENCES}

1. Food Agriculture Organization of the United Nations (2014) Species fact sheets: Megalaspis cordyla. FAO Fisheries and Aquaculture Department. www.fao.org/ fishery/species/3123/en.

2. al Sakaff H, Esseen M (1999) Occurrence and distribution of fish species off Yemen (Gulf of Aden and Arabian Sea). Naga ICLARM Q 22, 43-7.

3. Kuthalingam MDK (1959) A contribution to the life-histories and feeding habits of horse-mackerels, Megalaspis cordyla (Linn.) and Caranx mate (Cuv. and Val.) and notes on the effect of absence of light on the development and feeding habits of larvae and postlarvae of Megalaspis cordyla. J Madras Univ B 29, 76-96.

4. Datta NC, Deb S (1981) Anatomy of the olfactory apparatus of two marine India teleosts. J Inland Fish Soc India 13, 67-74.

5. Sreenivasan PV (1978) Observations on the fishery and biology of Megalaspis cordyla (Linnaeus) at Vizhinjam. Indian J Fish 25, 122-40.

6. Smith-Vaniz WF (1999) Carangidae. In: Carpenter KE, Niem VH (eds) FAO Species Identification Guide for Fishery Purposes. The Living Marine Resources of the Western Central Pacific. Volume 4. Bony fishes part 2 (Mugilidae to Carangidae). FAO, Rome. pp 2659-756.

7. Agusa T, Kunito T, Sudaryanto A, Monirith I, KanAtireklap S, Iwata H, Ismail A, Sanguansin J, Muchtar M, Tana TS, Tanabe S (2007) Exposure assessment for trace elements from consumption of marine fish in Southeast Asia. Environ Pollut 145, 766-77.

8. Naidu VA, Rao LM, Ramaneswari K (2008) Occurrence of heavy metals $(\mathrm{Zn}, \mathrm{Pb}, \mathrm{Cd}, \mathrm{Cu}$ and $\mathrm{Fe})$ in the edible tissue of Megalaspis cordyla of the coastal waters of Visakhapatnam, A.P. India. Asian Fish Sci 21, $13-9$.

9. Sivakami S (1995) Fishery and biology of the carangid fish Megalaspis cordyla (Linnaeus) off Cochin. J Mar Biol Assoc India 37, 237-48.

10. Saker Y, Jaiswar AK, Chakraborty SK, Swamy RP (2004) Morphometry and length-weight relationship of Megalaspis cordyla (Linnaeus, 1758) from Mumbai coast. Indian J Fish 51, 481-6.

11. Panda D, Chakraborty SK, Jaiswar AK, Kumar T, Behera PK (2011) Comparative length-weight relationship of two species of carangids Decapterus russelli (Ruppell, 1830) and Megalaspis cordyla (Linnaeus, 1758) from Mumbai waters. Indian J Fish 58, 33-7. 
12. Rajanna KB, Benakappa S, Anjanayappa HN (2006) Length-weight relationship and relative condition factor of Megalaspis cordyla (Linnaeus) from Mangalore coast. Environ Ecol 24S, 670-2.

13. Reuben S, Kasim HM, Sivakami S, Radhakrishnan Nair PN, Kurup KN, Sivadas M, Noble A, Somasekharan Nair KV, Raje SG (1992) Fishery, biology and stock assessment of carangid resources from the Indian seas. Indian J Fish 39, 195-234.

14. Zafar M, Mustafa MG, Haque MA (2000) Population dynamics of Megalaspis cordyla (Linnaeus, 1758) from northeastern part of the Bay of Bengal, Bangladesh. Indian J Fish 47, 163-8.

15. Hilborn R, Walters CJ (2001) Quantitative Fisheries Stock Assessment: Choice, Dynamics and Uncertainty, Chapman and Hall, New York, p 570.

16. Froese R (2006) Cube law, condition factor and weightlength relationships: history, meta-analysis and recommendations. J Appl Ichthyol 22, 241-53.

17. Wootton RJ (1990) Ecology of Teleost Fishes, Chapman and Hall, New York, US, p 404.

18. Hyslop EJ (1980) Stomach contents analysis-a review of methods and their application. J Fish Biol 17, 411-29.

19. Mansor MI, Mohd-Taupek MN, Ibrahim S, Kamariah I, Talib AA (1999) Population structure of commercially important fishes in the Malaysia waters, Survey Report, Department of Fisheries Malaysia.

20. Simon KD, Mazlan AG, Cob ZC, Samat A, Arshad A (2008) Age determination of archer fishes (Toxotes jaculatrix and Toxotes chatareus) inhibiting Malaysian estuaries. J Biol Sci 8, 1096-9.

21. Simon KD, Bakar Y, Temple SE, Mazlan AG (2010) Morphometric and meristic variation in two congeneric archer fishes Toxotes chatareus (Hamilton 1822) and Toxotes jaculatrix (Pallas 1767) inhabiting Malaysian coastal waters. J Zhejiang Univ Sci B 11, 871-9.

22. Simon KD, Mazlan AG, Samat A, Zaidi CC, Aziz A (2010) Size, growth and age of two congeneric archer fishes (Toxotes jaculatrix Pallas, 1767 and Toxotes chatareus Hamilton, 1822) inhabiting Malaysian coastal waters. Sains Malays 39, 697-704.

23. Simon KD, Bakar Y, Samat A, Zaidi CC, Aziz A, Mazlan AG (2009) Population growth, trophic level, and reproductive biology of two congeneric archer fishes (Toxotes chatareus, Hamilton 1822 and Toxotes jaculatrix, Pallas 1767) inhabiting Malaysian coastal waters. J Zhejiang Univ Sci B 10, 902-11.

24. Simon KD, Bakar Y, Mazlan AG, Zaidi CC, Samat A, Arshad A, Temple SE, Brown-Peterson NJ (2012) Aspects of the reproductive biology of two archer fishes Toxotes chatareus, (Hamilton 1822) and Toxotes jaculatrix (Pallas 1767). Environ Biol Fish 93, 491-503.

25. Ricker WE (1973) Linear regressions in fishery research. J Fish Res Board Can 30, 409-34.

26. Simon KD, Mazlan AG (2008) Length-weight and length-length relationships of archer and puffer fish species. Open Fish Sci J 1, 19-22.

27. Zar JH (1996) Biostatistical Analysis, 3rd edn, Prentice Hall International, New Jersey, London, p 662.

28. Spiegel MR (1991) Théorie et Applications de la Statistique, McGraw-Hill, Paris (in French), p 358.

29. Simon KD, Mazlan AG (2008) Trophodynamic analysis of archer fishes (Toxotes chatareus and Toxotes jaculatrix). In: Proceedings of the IOC/WESTPAC 7th International Scientific Symposium, Kota Kinabalu, Sabah, Malaysia, 21-25 May 2008. p 219.

30. Simon KD, Mazlan AG (2010) Trophic position of archerfish species (Toxotes chatareus and Toxotes jaculatrix) in the Malaysian estuaries. J Appl Ichthyol 26, 84-8.

31. Gunn JS, Milward NE (1985) The food, feeding habits and feeding structures of the whiting species, Sillago sihama (Forsskål) and Sillago analis Whitley from Townsville, North Queensland, Australia. J Fish Biol 26, 411-27.

32. Pauly D, Froese R, Sa-a P, Palomares ML, Christensen V, Rius J (2000) TrophLab Manual, ICLARM, Manila.

33. Pauly D, Trites AW, Capuli E, Christensen V (1998) Diet composition and trophic levels of marine mammals. ICES J Mar Sci 55, 467-81.

34. Pauly D, Palomares ML (2000) Approaches for dealing with three sources of bias when studying fishing down marine food web phenomenon. In: Briand F (ed) Fishing Down the Mediterranean Food Webs?, CIESM Workshop Series no. 12, pp 61-6.

35. Bagenal TB, Tesch FW (1978) Age and growth. In: Bagenal TB (ed) Methods for Assessment of Fish Production in Freshwaters, 3rd edn, Blackwell Scientific Publication, Oxford, pp 101-36.

36. Taskavak E, Bilecenoglu M (2001) Length-weight relationships for 18 Lessepsian (Red Sea) immigrant fish species from the eastern Mediterranean coast of Turkey. J Mar Biol Assoc UK 81, 895-6.

37. Kimmerer W, Avean SR, Bollens SM, Freyrer F, Grimaldo LF, Moyle PB, Nobriga M, Visintainer T (2005) Variability in length-weight relationships used to estimate biomass of estuarine fish form survey data. Trans Am Fish Soc 134, 481-95.

38. Özaydin O, Taskavak E (2006) Length-weight relationships for 47 fish species from Izmir Bay (eastern Aegean Sea, Turkey). Acta Adriat 47, 211-6.

39. Simon KD, Mazlan AG, Cob ZC (2013) Condition factors of two archerfish species from Johor coastal waters, Malaysia. Sains Malays 42, 1115-9.

40. Blaber SJM, Milton DA, Rawlinson NJF, Tiroba G, Nichols PV (1990) Diets of lagoon fishes of the Solomon Islands: Predators of tuna baitfish and trophic effects of baitfishing on the subsistence fishery. Fish Res 8, 263-86.

41. Stergiou KI, Karpouzi VS (2002) Feeding habits and trophic levels of Mediterranean fish. Rev Fish Biol Fish 11, 217-54. 